\title{
Lysosomal-Associated Transmembrane Protein 5
}

National Cancer Institute

\section{Source}

National Cancer Institute. Lysosomal-Associated Transmembrane Protein 5. NCl

Thesaurus. Code C150083.

Lysosomal-associated transmembrane protein 5 (262 aa, $\sim 30 \mathrm{kDa}$ ) is encoded by the human LAPT M5 gene. This protein is involved in the regulation of both hematopoietic cell differentiation and embryogenesis. 